\title{
SCIENCE TIME
}

\section{ОСОБЕННОСТИ ОРГАНИЗАЦИИ НАЛОГООБЛОЖЕНИЯ НАСЕЛЕНИЯ В РОССИЙСКОЙ ФЕДЕРАЦИИ}

Ермакова Людмила Владимировна, Мельгуй Андрей Эдуардович, Дедова Ольга Васильевна, Брянский государственный университет им. академика И.Г. Петровского, г. Брянск

E-mail: tkdtkd@yandex.ru E-mail:mae1089@yandex.ru E-mail:o.vod2012@yandex.ru

Abstract. In article the modern system of the domestic taxation of the population is analyzed. The basic principles, tendencies, postulates and functions of the taxation of physical persons, and also the main problems of its implementation are considered.

Keywords. System of the taxation of the population; principles of the taxation of physical persons; tendencies and basic provisions of the taxation of physical persons; a role of the taxation of physical persons in forming of the government budget.

Аннотация. В статье анализируется современная система отечественного налогообложения населения. Рассматриваются основные принципы, тенденции, постулаты и функции налогообложения физических лиц, а также главные проблемы ее реализации.

Ключевые слова: система налогообложения населения; принципы налогообложения физических лиц; тенденции и базисные положения налогообложения физических лиц; роль налогообложения физических лиц в формировании государственного бюджета.

Система налогообложения, как юридических лиц, так и населения в России строится на основе двух базовых документов: Конституции РФ и Налогового кодекса РФ и основывается на следующих основных принципах:

а) справедливости, предполагающего всеобщность и равномерность 


\section{SCIENCE TIME}

налогообложения населения пропорционально получаемым им доходам;

б) определенности, подразумевающего своевременное и полное информационное обеспечение граждан о величине, порядке расчета, месте и сроках уплаты причитающихся налогов;

в) комфортности, обеспечивающего удобную среду для исполнения гражданином своих налоговых обязанностей в удобной для него форме и в удобное для него время;

г) экономичности, создающего условия для сокращения временных затрат по процедуре исполнения населением своих налоговых обязательств [1].

Во всех странах применяются различные варианты налогообложения населения, однако эта система строится на идентичных тенденциях налогообложения:

- всеобщий охват налогами экономически активного населения;

- активное использование косвенного налогообложения;

- применение в налогообложении доходов населения прогрессивных либо пропорциональных ставок, которые характеризуют степень комфортности осуществления трудовой деятельности в той или иной стране [5].

Базисными положениями для обеспечения исполнения населением своих налоговых обязательств являются следующие:

- к уплате подлежат только законно установленные налоги и сборы, которые не могут иметь дискриминирующих составляющих для отдельных категорий населения;

- все налоги и сборы, а также дифференциация налоговых ставок должна быть экономически обоснованы и взиматься только законодательно уполномоченными на это государственными органами;

- любые коллизии налогового законодательства, которые вносят неопределенность в налоговую систему, должны трактоваться в пользу физического лица, уплачивающего налог или сбор [7].

Система налогообложения населения в России строится на постулате поддержки государства каждым гражданином страны путем перечисления в бюджет экономически обоснованной части полученных им доходов, которые направляются для реализации государством своих социальных обязательств перед населением. При этом экономическая составляющая налоговых взаимоотношений государства и населения складывается на основе денежного изъятия части полученных доходов последнего для формирования бюджетов различного уровня и государственных внебюджетных фондов [3].

Налоги обеспечивают связь экономически активного населения с органами федеральной государственной власти и местного самоуправления и задействуют работающего гражданина в процессе формирования государственных доходов [6]. При этом реализуется важный аспект привлечения экономически активных 
членов общества в процедуру осуществления общественного контроля за рациональным распределением государственных финансовых ресурсов. Это происходит в результате того, что они формируются, в том числе, за счет изъятия части доходов экономически активного населения, которое помимо участия в формировании бюджетных средств страны получает посыл для осуществления контрольных действий за их эффективным использованием.

Экономическая сущность налогообложения физических лиц выражается в фискальной и регулирующей функциях налогов. Классификацию налогообложения населения следует осуществлять по механизму их формирования - прямые и косвенные, а также по объектам налогообложения - с доходов физического лица, имущественные или денежные сборы, которые взимаются уполномоченными органами за выполнение определенных функций в части обслуживания населения в предусмотренных законодательством размерах (государственная пошлина).

Действующее налоговое законодательство предусматривает налогообложение физических лиц, относящихся к следующим категориям: граждане России; лица, не имеющие гражданства и иностранные граждане, получающие доходы и (или) являющими собственниками имущества на территории и в юрисдикции Российской Федерации, подлежащие налогообложению в соответствии с отечественным законодательством. Именно эти категории плательщиков налогов и составляют понятие физические лица, на которых распространяется действующее национальное налоговое законодательство. Если они являются участниками экономических отношений, которые попадают в сферу налогообложения, то им предстоит уплата следующих налогов и сборов, в зависимости от видов осуществления экономической деятельность и состава имущества, приобретенного на территории Российской Федерации:

- налог на доходы физических лиц [4];

- земельный налог;

- налог на имущество физических лиц;

- транспортный налог;

- государственная пошлина;

- отчисления в государственные внебюджетные фонды.

Способы взимания налогов существенно различаются. Например, налог на доходы физических лиц может взиматься как безналичным путем перечисления налога налоговым агентом, являющимся работодателем, так и декларационным способом, когда физическое лицо обязано задекларировать свои доходы, полученные самостоятельно. А вот уплата налога на имущество осуществляется по полученным гражданином налоговым уведомлениям.

Налоги в формировании поступлений государственного бюджета, в 


\section{SCIENCE TIME}

которых задействовано население, подразделяются на следующие виды:

- напрямую взимаемые налоги и сборы с населения, в категорию которых относятся налог на доходы физических лиц, налог на имущество, транспортный налог, земельный налог, таможенная пошлина;

- косвенные налоги, конечным плательщиком которых является, в том числе, и население (налог на добавленную стоимость и акцизы);

- отчисления населения по налогу на доходы физических лиц и в государственные внебюджетные фонды как налоговых агентов в случае осуществления не связанной с трудовыми отношениями с юридическими лицами экономической деятельности и найма работников для удовлетворения собственных потребностей, в результате которых физическое лицо выступает в качестве работодателя.

В целом система налогообложения населения в Российской Федерации достаточно сбалансирована, но имеет предпосылки для еe качественного переформатирования.

Основной дискуссионной проблемой является применение в отечественной практике налогообложения пропорциональных ставок в исчислении налога на доходы физических лиц [2]. Хотя в российском налоговом законодательстве предусмотрено значительное количество льгот, учитывающих трудности социально незащищенных слоев населения, но пропорциональные ставки все равно не способствуют принципу социальной справедливости. Доля уплачиваемого налога на доходы физических лиц от получаемых доходов основных, определяющих социальную структуру страны слоев населения, несравнима с категорией населения, относящихся к элите и получающей сверхдоходы, зачастую только в силу своего социального положения. Такое состояние системы налогообложения доходов физических лиц не способствует реализации принципа справедливости в налогообложении и чревато проявлением социальных волнений.

Так, в большинстве экономических стран применяется прогрессивная шкала взимания подоходного налога, которая нивелирует разницу социального положения различных слоев населения, и в тоже время способствует получению более высоких доходов наиболее экономически активным группам населения.

Таким образом, налоговая система обложения населения в Российской Федерации имеет достаточно обоснованную экономическую структуру, но в тоже время обладает некоторыми недостатками, требующими корректировки как в системе законодательного обеспечения, так и в системе налогового администрирования. 


\section{SCIENCE TIME}

\section{Литература:}

1. Гудкова О.В., Ермакова Л.В. Вопросы налогообложения НДФЛ в 2016 году // Новая наука: От идеи к результату. 2016. № 4-1. С. 133-137.

2. Дворецкая Ю. А., Ковалева Н. Н., Мельгуй А. Э. Расчеты с персоналом по оплате труда: современные подходы и тенденции // Вестник Брянского государственного университета - 2015. - № 2. - С. 331-335.

3. Кузнецова О.Н. Новая модель учета вознаграждений работникам предприятия // В мире научных открытий. - 2013. - № 4.1 (40). - С. 260-270.

4. Мельгуй А.Э., Дворецкая Ю.А. Вознаграждения работникам: новая категория в российском бухгалтерском учете // Вестник Брянского государственного университета. - 2012. - № 3 (2). - С. 289-293.

5. Мельгуй А.Э., Катков Ю.Н., Ковалева Н.Н., Дворецкая Ю.А., Шварц М.Р. Бухгалтерский учет и анализ. Учебное пособие / Под научной редакцией А.Э. Мельгуй - Брянск: ООО «Ладомир», 2012. - 339 с.

6. Мельгуй А.Э., Ковалева Н.Н., Дворецкая Ю.А. Налогообложение имущества физических лиц: региональный аспект // Вестник Брянского государственного университета. - 2015. - № 3. - С. 307-313.

7. Хоружий Л.И., Дедова О.В., Катков Ю.Н. Учетно-аналитическое обеспечение и налогообложение заработной платы в современных условиях хозяйствования // Бухучет в сельском хозяйстве. - 2015. - № 5-6. - С. 56-69. 